Панфілова Тамара Олександрівна кандидат економічних наук, старший науковий співробітник, провідний науковий співробітник сектору міжнародних фінансових досліджень ДУ «Інститут економіки та прогнозування НАН України», вул. Панаса Мирного, 26, м. Київ, 01011, тел.: (066) 154-54-47, e-mail: tamara.panfilova@gmail.com, https://orcid.org/0000-0002-1410-6258.

\title{
ЗАБЕЗПЕЧЕННЯ СТІЙКОСТІ НАЦІОНАЛЬНИХ ФІНАНСОВИХ СИСТЕМ В УМОВАХ ПАНДЕМІЇ COVID-19
}

Анотація. Пандемія COVID-19 другій рік випробовує глобальну та національні фінансові системи на стійкість, здатність забезпечити стабільність їх функціонування у середньостроковій перспективі. Мета дослідження полягає у методологічному обгрунтуванні систематизації механізмів забезпечення стійкості національних фінансових систем в умовах пандемії COVID-19 задля розвитку у напрямку стабільності з урахуванням досвіду окремих країн, у т.ч. України. Обгрунтовано положення, що концептуальні основи розкриття сутності поняття «фінансова стійкість» та його взаємозв'язку із поняттям «фінансова стабільність» формуються й розвиваються відповідно до методологічних підходів визначення терміну «фінансова система». Основою виміру фінансової стійкості є «діапазон стабільності» груп показників та їх граничних меж відповідно до складових елементів фінансової системи.

Проведений аналіз методів та інструментів попередження та подолання кризових явищ фінансового характеру 3 метою забезпечення стабільності національних фінансових систем дозволив сформулювати методологічне положення, що найбільш ефективним є групування антикризових методів за сферами повноважень відповідних національних регуляторів - національних банків, міністерств фінансів та інших регуляторних органів. Зокрема основним завданням забезпечення стійкості державних фінансів $\epsilon$ виявлення тих ризиків, які в перспективі можуть викликати перегляд бюджетної політики та іiї параметрів, стратегії управління державним боргом в довгостроковій перспективі. Основні індикатори стійкості державних фінансів формуються 3 використанням фіскальних правил національного й наднаціонального рівнів. Національні банки в межах своїх повноважень забезпечують фінансову стійкість банківської системи, платіжної системи, грошово-кредитного i валютного ринків методами макропруденційної та монетарної політики. 
Запропонований методологічний підхід реалізовано при аналізі досвіду України та країн-членів СС щодо забезпечення стійкості фінансових систем в умовах пандемії COVID-19.

Ключові слова: стійкість та стабільність фінансової системи, ризик, державний борг, дефіцит державного бюджету, макропруденційна політика, пандемія COVID-19.

Panfilova Tamara Alexandrovna PhD (Econ.), Senior Researcher, Leading Researcher of the Sector of International Financial Research, Institute for Economics and Forecasting of the NAS of Ukraine, Panasa Myrnoho St., 26, Kyiv, 01011, tel.: (066) 154-54-47, e-mail: tamara.panfilova@gmail.com, https://orcid.org/0000-00021410-6258.

\title{
ENSURING THE SUSTAINABILITY OF NATIONAL FINANCIAL SYSTEMS IN THE CONTEXT OF THE COVID-19 PANDEMIC
}

\begin{abstract}
The COVID-19 pandemic the second year tests the global and national financial systems for sustainability, the ability to ensure the stability of their functioning in the medium term. The purpose of the study is to methodologically substantiation of systematization the mechanisms for ensuring the stability of national financial systems in the context of the COVID-19 pandemic for development towards stability, taking into account the experience of individual countries, including Of Ukraine. The position is substantiated that the conceptual bases of revealing the essence of the concept of "financial sustainability" and its interrelation with the concept of "financial stability" are formed and developed according to methodological approaches of definition of the term "financial system". The basis for measuring financial stability is the "stability amplitude " of groups of indicators and their limits in accordance with the components of the financial system.

The analysis of methods and tools for preventing and overcoming financial crises in order to ensure the stability of national financial systems allowed to formulate a methodological position, which is the most effective grouping of anti-crisis methods by the respective national regulators - national banks, ministries of finance and other regulators. In particular, the main task of ensuring the sustainability of public finances is to identify those risks that in the long run may cause a revision of fiscal policy and its parameters, public debt management strategy in the long run. The main indicators of the sustainability of public finances are formed using fiscal rules at the national and supranational levels. National banks, within their powers, ensure the financial sustainability of the banking system, payment system, monetary and foreign exchange markets through macroprudential and monetary policies.
\end{abstract}


The proposed methodological approach is implemented in the analysis of the experience of Ukraine and EU member states to ensure the sustainability of financial systems in the context of the COVID-19 pandemic.

Keywords: sustainability and stability of the financial system, risk, public debt, state budget deficit, macroprudential policy, COVID-19 pandemic.

Постановка проблеми. Запорукою сталого економічного зростання будь-якої країни світу є стабільність національної фінансової системи. Процеси фінансової глобалізації, частота i розмаїття фінансових криз на національному та наднаціональному рівнях актуалізували дослідження науковців та експертів щодо сутності поняття «фінансова стійкість» та «фінансова стабільність».

Аналіз останніх досліджень $і$ публікацій. Теоретико-методологічні основи фінансової стабільності та нестабільності грунтовно систематизовано Г.Дж. Шинами та Maria Vasilescu [1;2]. У численних публікаціях зарубіжних та вітчизняних вчених та експертів розкриваються різні аспекти фінансової стійкості банківських систем та ринків, сфери державних фінансів, зміни базових співвідношень щодо стабільності грошової одиниці та стійкості фінансової системи, взаємозв'язку поняття фінансової стійкості із поняттям «фінансова стабільність» та «фінансова нестабільність» тощо [3-10]. Огляд публікацій дозволив виявити розмаїття тлумачень фінансової стабільності та фінансової стійкості, що потребує певної систематизації і розмежування сутності понять, групування методів та інструментів попередження та подолання кризових явищ фінансового характеру.

Відсутність досвіду реагування національних владних структур на ескалацію загроз фінансовій стабільності в умовах пандемії COVID-19 та неоднозначність попередніх оцінок ефективності запроваджених антикризових методів та інструментів зумовлює необхідність їх систематизації.

Мета статті полягає у методологічному обтрунтуванні механізмів забезпечення стійкості національних фінансових систем в умовах пандемії COVID-19 задля розвитку у напрямку стабільності з урахуванням досвіду окремих країн, у т.ч. України.

Виклад основного матеріалу. На нашу думку концептуальні основи розкриття сутності понять «фінансова стійкість» та «фінансова стабільність» формуються й розвиваються відповідно до методологічних підходів визначення терміну «фінансова система».

Виділяють такі основні підходи до визначення терміну «фінансова система»: а) $з$ позиції теорії фінансів - як сукупність сфер і видів фінансових відносин або як сукупність фінансових ринків [11, с. 30]; б) з позиції теорії інституціоналізму як сукупність фінансових інститутів (установ) [11, с. 30]; в) з позицій організації 
управління - як «мережа фінансових інститутів та ринків, що оперують різними фінансовими інструментами, за допомогою яких здійснюються усі операції 3 фінансовими ресурсами: обіг грошової маси, кредитування та позичання фінансових ресурсів, зовнішньоекономічна діяльність» [12, с. 7]; г) з позиції економічної теорії - як «форма організації грошових відносин між усіма суб’єктами відтворювального процесу щодо розподілу й перерозподілу сукупного суспільного продукту» $[12$, с. 8$]$.

У Керівництві по складанню показників фінансової стійкості МВФ зазначено, що «фінансова система складається 3 інституційних одиниць і ринків, які взаємодіють між собою, зазвичай складним чином, з метою залучення коштів для інвестицій i забезпечення роботи механізмів фінансування комерційної діяльності, в тому числі платіжних систем» $\quad[13$, с. 11$]$. Інституційна одиниця являє собою структуру, таку як домашнє господарство, корпорація або державна установа. Органи державного управління мають повноваження встановлювати податки, залучати позикові кошти, розподіляти товари і послуги в суспільстві в цілому або серед окремих фізичних осіб і перерозподіляти доходи. [13, с. 14].

Саме останнє визначення достатньо повно віддзеркалює складність i структуру фінансової системи і може бути покладено в основу систематизації механізмів забезпечення іï стійкості. При цьому структуризація системи можлива: за сферами діяльності певних інститутів - державних і корпоративних фінансів, фінансів домогосподарств; за сферами функціонування фінансових ринків та грошово-кредитної системи тощо.

Сутність відмінних рис понять «фінансова стабільність» та «фінансова стійкість» розкривається нами через використання тлумачення Г.Дж. Шиназі: «Фінансова система може вважатися стабільною, якщо вона: 1) полегшує ефективний розподіл економічних ресурсів як в просторі, так і в часі, а також інші фінансово-економічні процеси (наприклад, заощадження та інвестування коштів, кредитування та запозичення, освіту i розподіл ліквідності, формування цін активів i, в кінцевому підсумку, накопичення багатства і зростання виробництва); 2) дозволяє оцінювати, котирувати і розподіляти фінансові ризики і здійснювати управління ними; 3) зберігає здатність виконувати ці важливі функції навіть під впливом зовнішніх потрясінь або при посиленні диспропорцій, насамперед за допомогою механізмів самокорекції?» [14, с.2,8].

Ключове положення щодо сутності фінансової стійкості, криється у виразі «діапазоні стабільності»: «Фінансова система знаходиться в діапазоні стабільності, коли вона здатна сприяти (а не перешкоджати) функціонуванню економіки та розсіювати фінансові дисбаланси, що виникають ендогенно або внаслідок значних несприятливих та непередбачуваних подій» [14, с. 8]. Саме діапазон стабільності $є$ основою виміру фінансової стійкості за допомогою груп 
показників та їх граничних меж відповідно до складових елементів фінансової системи. Наближення величин певних показників до таких меж означає, що фінансова система втрачає здатність виконувати свої функції, що потребує вжиття антикризових заходів. Термін «розсіює фінансові дисбаланси» означає рух у напрямку стабільності - подалі від граничних меж [14].

Оцінка фінансових ризиків здійснюється 3 метою виявлення потенційних порушень у фінансових системах. Порушення функціонування однієї з ланок або сфер фінансової системи може підірвати стабільність всієї системи, і навпаки, якщо система досить ефективно функціонує, виникнення проблем в одній зі сфер або ланок необов’язково є загрозою для їі загальної стабільності [6]. Різні види ризику вимагають прийняття спеціалізованих антикризових заходів фінансової політики.

В цьому зв’язку слід зазначити, що не існує загально узгодженого комплексу індикаторів (показників) фінансової стійкості, оскільки національні фінансові системи є доволі складними, мають різний вимір, відмінні структури інститутів, банківських систем та ринків. У дослідженнях щодо стійкості національних фінансових систем достатньо часто зустрічаються оцінки критеріїв та інструментів забезпечення стійкості за видами політики в окремих секторах банківському, кредитному, платіжному, валютному, пенсійному, бюджетному, податковому, страховому тощо. Особливо поширеними є дослідження щодо стійкості банківської системи та сфери державних фінансів.

Важливу роль у розв’язанні проблем забезпечення фінансової стійкості відіграють міжнародні організації та спеціалізовані установи. Зокрема МВФ i Світовий банк розробили Програму оцінки фінансового сектора (FSAP), в рамках якої передбачено: проведення оцінки надійності окремих підсистем (перш за все, банківської), якості банківського, страхового, фінансового ринків та нагляду за прийнятими міжнародними стандартами; проведення стрес-тестів; оцінку здатності монетарної влади ефективно реагувати у випадку системної кризи тощо. Інші міжнародні організації проводять дослідження окремих секторів фінансової системи. Мова йде про Банк міжнародних розрахунків (Базельський комітет 3 банківського нагляду), ОЕСР, Міжнародну організацію регуляторів ринків цінних паперів (IOSCO), Міжнародну асоціацію органів страхового нагляду (IAIS), Раду 3 міжнародних стандартів фінансової звітності (IASB) тощо. В більшості країн світу створено Ради або Комітети з фінансової стабільності і розвитку фінансового ринку $[3 ; 5]$.

Особливу роль щодо питань підвищення стійкості глобальної фінансової системи відіграє створена після глобальної кризи 2008-2009 років Рада 3 фінансової стабільності, в рамках якої відбуваються зустрічі повноважних представників національних центральних банків, міністерств фінансів i 
регуляторів фінансових ринків найбільш розвинених країн світу, а також провідних міжнародних фінансових організацій. Рада відіграє роль своєрідного координатора дій національних фінансових регуляторів i міжнародних економічних та фінансових організацій при розробці рекомендацій, що виносяться на обговорення під час зустрічей як глав держав i урядів, так i керівників центральних банків і міністрів фінансів [12].

Система показників-індикаторів, які формуються в кожній країні, дозволяє завчасно сигналізувати про потенційні загрози та вживати заходів щодо їх запобігання [15]. При цьому для забезпечення адекватної оцінки фінансової стійкості країни слід аналізувати використовувані індикатори у динаміці протягом як мінімум 4-5 років. Якщо розраховані значення індикаторів визнаються як небезпечно близькі до порогових значень, необхідне вжиття антикризових заходів, спрямованих на повернення величин індикаторів до прийнятного діапазону стабільності.

Досвід еволюції методів та інструментів попередження та подолання кризових явищ фінансового характеру 3 метою забезпечення стабільності національних фінансових систем дозволяє сформулювати положення, що найбільш ефективним $є$ групування антикризових методів за сферами повноважень відповідних національних регуляторів - національних банків, міністерства фінансів або інших регуляторних органів. Концептуальні основи реалізації методів та інструментів забезпечення фінансової стійкості в межах компетенції міністерства фінансів визначаються основними засадами фіскальної (бюджетно-податкової) політики та управління державним боргом. Національні банки в межах своєї компетенції реалізують монетарну та макропруденційну політику, здійснюють валютне регулювання, регулювання ринків небанківських фінансових послуг тощо. У цих установах створюються спеціальні підрозділи 3 фінансової стабільності, оприлюднюються звіти про фінансову стабільність, монетарний та макроекономічний огляд та огляд банківського сектору.

Використання запропонованого підходу дозволить проаналізувати основні показники стійкості національної фінансової системи окремих країн в умовах пандеміï COVID-19.

\section{Забезпечення стійкості сектору державних рінансів.}

Основним завданням аналізу стійкості державних фінансів $є$ виявлення тих ризиків, які в перспективі можуть викликати перегляд бюджетної політики та іï параметрів в довгостроковій перспективі [15, с. 157].

Основні індикатори стійкості державних фінансів формуються 3 використанням фіскальних правил національного й наднаціонального рівнів. «Фіскальні правила - це законодавчі або нормативні обмеження довгострокового характеру на фіскальну політику у формі кількісних лімітів на основні бюджетні 
агрегати. Такі кількісні ліміти відображаються в національному законодавстві або міжнародних договорах та є обов'язковими для виконання органами державної влади» [16, с. 45].

Згідно світового досвіду, фіскальні правила класифікуються як правила заборгованості (боргу), правила бюджетного балансу, правила витрат або правила надходження бюджетних коштів $[17$, p.5; 16]. Правила боргу встановлюють явний ліміт або мету на державний борг у відсотках від ВВП.

В Україні загальний обсяг державного боргу й гарантованого державою боргу на кінець бюджетного періоду не може перевищувати 60 \% річного номінального обсягу ВВП. Існують i обмеження на борги місцевого самоврядування на рівні 200 \% надходжень до бюджету розвитку.

Прозорі процедури прийняття рішень у фіскальній політиці припускають наявність середньо- i довгострокових прогнозів розвитку сектора державних фінансів. Вони дозволяють економічним агентам коригувати свою поведінку 3 урахуванням майбутніх змін в соціальній та податковій політиці, програми державних інвестицій. Складовою фіскального прогнозування є виявлення та управління ризиками в бюджетних процедурах для реагування на виклики, пов’язані 3 невизначеністю внутрішнього економічного середовища i впливом зовнішніх чинників. Оцінюється взаємозв’язок між системою управління державними фінансами та цілями економічної політики.

В Україні відповідним документом є, наприклад, «Інформація про фіскальні ризики та їх вплив на показники державного бюджету у 2021 році» [18], опублікована Міністерством фінансів. У зазначеному документі відзначено чутливість державних фінансів до таких груп фіскальних ризиків: макроекономічні ризики, ризики, пов'язані із державним боргом та державними гарантіями, діяльністю суб’єктів господарювання державного сектору економіки, виконанням плану надходжень від приватизації державного майна, фінансовим сектором, сферою пенсійного забезпечення. Оцінки ризиків створюють підгрунтя для вжиття адекватних заходів, спрямованих на мінімізацію можливого негативного впливу на бюджетні показники та забезпечення повного і вчасного фінансування основних зобов'язань держави.

Згідно альтернативного кризового сценарію «за підсумками 2023 року не вдасться вийти на допандемічний рівень розвитку. Реальний ВВП становитиме лише 94 - 95 \% рівня 2019 року, в той час як за базовим сценарієм наприкінці 2023 року прогнозується перевищення рівня розвитку 2019 року на 8,7 \%. За цим сценарієм прогнозується падіння ВВП у 2021 році на рівні 4 - 5 \% 3 подальшим помірним зростанням у середньому за 2022 - 2023 роки на рівні 1,8 \% щороку (за базовим сценарієм на 4,5 \% відповідно)» [18, с. 10].

За підсумками 2020 року Уряду України вдалося утримати дефіцит 
держбюджету в межах граничного показника: фактичний дефіцит склав 217,6 млрд. грн., або 5,2\% ВВП, що на 81 млрд. грн.. менше від запланованого. Для порівняння, величина показника збільшилася із 2\% ВВП у 2019 році до затверджених 7,5\% на 2020 рік, план на 2021 рік - 6\% [18, с. 14;19].

Міністерство фінансів застерігає від актуалізації у 2021 р. фіскальних ризиків, що спричинені високими витратами за державним боргом: на період до 2022 року «припадають пікові платежі 3 погашення та обслуговування державного боргу, в основному через початок погашення ОЗДП, випущених у 2014 - 2016 роках під гарантію США та у 2015 році внаслідок реструктуризації державного та гарантованого державою зовнішнього боргу, а також через значні платежі за кредитами МФО (в основному перед МВФ) та за ОВДП, номінованими як в національній, так і в іноземних валютах. Ризики державного боргу можуть посилюватись в разі ускладнення доступу України до міжнародних ринків капіталу» [18, с. 14]. Національний банк України зазначає, що «у 2021-2022 роках Україні необхідно буде сплатити понад 17 млрд. дол. за державним i гарантованим державою боргом в іноземній валюті. Це еквівалентно близько $65 \%$ міжнародних резервів станом на початок грудня. ... Однак, щоб не допустити появи значних дисбалансів та витрачання резервів, Україні потрібно зберігати постійний доступ до кредитів МФО та зовнішніх приватних ринків капіталу» [20, с. 12].

Крім зростання власне державного боргу прогнозується збільшення витрат, пов'язаних із гарантованим державою боргом. Станом на 31.12.2019 гарантований державою борг становив 236,93 млрд. грн.., або 5,9 \% ВВП (в тому числі борг Національного банку перед МВФ 170,6 млрд. грн., або 7,2 млрд. дол. США) [18, с. 14]. У 2021 році такі можуть скласти понад 4,9 млрд. грн. і містять валютнокурсові ризики. «В ухваленому бюджеті граничний обсяг надання державних гарантій встановлено в сумі до 88.7 млрд. грн. Це більше ніж утричі перевищує ліміт, передбачений Бюджетним кодексом й може призвести до суттєвих витрат за такими зобов'язаннями в наступних бюджетних періодах» [20, с. 12].

У рамках запровадженого в Україні середньострокового бюджетування, Мінфін розробляє і оприлюднює Середньострокову стратегію управління державним боргом, якою передбачено досягнення не тільки кількісних, але й якісних цілей, спрямованих на зниження ризиків державного боргу. Так, у червні 2019 року відповідно до частини десятої статті 16 Бюджетного кодексу України Кабінет Міністрів України затвердив Середньострокову стратегію управління державним боргом на 2019-2022 роки [21]. Основними заходами, які планувалося здійснити для реалізації Стратегії, були: збільшення частки державного боргу у національній валюті; залучення іноземних інвесторів до інвестування в облігації у національній валюті; подовження середнього строку до погашення державних цінних паперів і забезпечення рівномірного графіку 
погашення державного боргу; здійснення операцій 3 активного управління державним боргом 3 метою зменшення пікових навантажень на державний бюджет та стимулювання попиту на державні цінні папери; проведення роботи із забезпечення повноцінного доступу України на міжнародний ринок капіталу; подальше удосконалення політики управління державним боргом, в тому числі шляхом створення та ефективного функціонування Агентства 3 управління державним боргом 3 використанням найкращих світових практик; розширення співпраці з міжнародними фінансовими організаціями, зокрема Світовим банком, Міжнародним валютним фондом, Європейським банком реконструкції та розвитку, Свропейським інвестиційним банком тощо. Контроль за ризиками державного боргу проводиться на основі оцінки показників ризику рефінансування, ліквідності, а також відсоткового, валютного та бюджетного ризиків та ризиків, пов'язаних з управлінням державним боргом.

Проте, через поширення пандемії COVID-19, розроблення Стратегії у 2020 році зупинено Законом України від 13.04.2020 № 553-IX «Про внесення змін до Закону України «Про Державний бюджет України на 2020 рік» (абзац третій пункту 2 Прикінцевих положень), що набрав чинності 18 квітня 2020 року [18, с. 13].

За оцінками Міністерства фінансів «у 2021 році лишається актуальним потенційний ризик, пов’язаний зі збільшенням обсягу державного боргу, зумовлений необхідністю державної підтримки банківської системи шляхом капіталізації державних банків та Фонду гарантування вкладів фізичних осіб, а також суб’єктів господарювання державного сектору шляхом як капіталізації, так і надання державних гарантій за їх борговими зобов’язаннями» [18, с. 15].

У світовій практиці особливе значення в процесі управління державним боргом має розрахунок індикаторів оцінки фінансового впливу на фінансову стійкість країни, до числа яких відносяться [7, с. 22-23; 22]: 1) непогашений державний борг (у тому числі заборгованість по відсоткам), у відсотках до ВВП; 2) борговий тягар на душу населення; 3) дефіцит бюджету, у відсотках до ВВП; 4) процентні платежі, у відсотках до ВВП; 5) частка знову отриманих позик в суспільно-державних витратах; 6) частка процентних платежів в загальних суспільно-державних витратах; 7) співвідношення процентних витрат і загальної кількості податкових надходжень.

Станом на кінець 2020-го року відношення державного боргу до ВВП в Україні становило 53,9\%, а відношення гарантованого державою боргу до ВВП становило 7,0 \%. Показник державного та гарантованого державного боргу до ВВП станом на кінець 2020-го року становив 60,9\% [23].

В цілому «для мінімізації фіскальних ризиків, пов’язаних із управлінням державним боргом та гарантованим державою боргом, є необхідним: повернення до практики дотримання фіскальних правил, визначених Бюджетним кодексом 
України, в першу чергу - обмеження на дефіцит державного бюджету у 3\% до ВВП; збільшення частки державного боргу у національній валюті; продовження середнього строку до погашення і забезпечення рівномірного графіка погашення державного боргу; обмеження надання державних гарантій виключно для реалізації інвестиційних проєктів із забезпеченням контролю за їх впровадженням; залучення довгострокового пільгового фінансування від міжнародних фінансових організацій, зокрема МВФ, МБРР та СС; продовження розвитку системних та довгострокових відносин із інвесторами» [18, с. 13].

Наведені дані щодо ідентифікації фіскальних ризиків для сектору державних фінансів України, є співставними із даними з порушеннями фіскальних правил країнами СС в умовах пандемії COVID-19.

Відомими фіскальними правилами наднаціонального характеру є вимоги до країн-учасниць ЄС, встановлені Пактом стабільності і зростання на основі Маастрихтського договору: дефіцит держбюджету не може перевищувати 3 \% від ВВП; сукупний державний борг не повинен перевищувати 60 \% від ВВП.

Глобальна фінансова криза 2008 р. спонукала країни ЄС до перегляду Пакту стабільності і зростання з метою покращання бюджетної дисципліни. Оновленим Пактом було передбачено: встановлення середньострокових орієнтирів щодо бездефіцитних бюджетів; державний борг країн, що перевищили граничний показник 60 \% ВВП, повинен щороку скорочуватися на одну двадцяту обсягу перевищення; запровадження Свропейською комісією ступінчастої та автоматизованої системи штрафів та санкцій; оприлюднення бюджетних даних на основі чітких стандартів, які контролює Європейська служба статистики (Євростат).

Пандемія COVID-19 змусила країни EC порушити зазначені фіскальні правила, про що свідчать дані таблиці 1. Зокрема вже з першого кварталу 2020 року спостерігається «злам» профіцитів державних бюджетів країн-членів на дефіцити. Вже у другому кварталі 2020 року дефіцит бюджетів країн СС-27 та зони євро перевищив 11\% ВВП. Серед найбільш уразливих країн виявилися Іспанія (-24,6\%), а також Кіпр, Польща та Словенія, у яких дефіцит бюджету перевищив 16\%. Проте вже в третьому кварталі дефіцити бюджетів цих країн не перевищили 3\%. Для решти країн ЄС Значні величини дефіцитів спостерігалися $\mathrm{i}$ в третьому кварталі, що дає підстави прогнозувати перевищення цього показника за підсумками 2020 року встановленого критерію у 3\%. Для Великобританії, яка проходила важку процедуру виходу із ЄС, дефіцит бюджету у другому та третьому кварталі становив $-24,8$ та $-13,6 \%$. 
Таблиця 1

Дефіцит (-) та профіцит (+) державного бюджету країн СС та Великобританії, квартальні дані 2019-2020 рр., \% ВВП

\begin{tabular}{|c|c|c|c|c|c|c|c|}
\hline Країна/квартал & 2019-Q1 & 2019-Q2 & 2019-Q3 & 2019-Q4 & 2020-Q1 & 2020-Q2 & 2020-Q3 \\
\hline Зона євро 19 країн & $-2,1$ & $-0,1$ & $-0,7$ & 0,3 & $-4,1$ & $-11,7$ & $-5,7$ \\
\hline ЄС 27 країн & $-1,7$ & 0,2 & $-0,6$ & $-0,1$ & $-3,9$ & $-11,2$ & $-5,3$ \\
\hline Іспанія & $-1,3$ & $-7,1$ & 2,9 & $-5,6$ & $-3,6$ & $-24,6$ & $-1,0$ \\
\hline Кіпр & 1,2 & 2,5 & 6,6 & $-4,6$ & 3,9 & $-16,5$ & $-1,5$ \\
\hline Польща & 2,8 & $-0,4$ & 0,1 & $-4,5$ & $-2,2$ & $-16,3$ & $-2,9$ \\
\hline Словенія & $-0,6$ & 0,7 & 1,1 & 0,8 & $-6,3$ & $-16,3$ & $-1,2$ \\
\hline Австрія & $-1,2$ & 1,7 & 2,1 & 0,1 & $-2,3$ & $-15,1$ & $-6,0$ \\
\hline Мальта & $-1,3$ & 1,3 & 1,1 & 0,8 & $-9,7$ & $-14,4$ & $-9,8$ \\
\hline Греція & $-4,1$ & 0,7 & 4,9 & 3,8 & $-6,1$ & $-12,8$ & $-4,8$ \\
\hline Нідерланди & 5,4 & 0,3 & $-0,2$ & 1,4 & 4,6 & $-12,7$ & $-6,2$ \\
\hline Франція & $-7,1$ & $-2,8$ & $-3,8$ & 1,5 & $-9,9$ & $-12,6$ & $-4,5$ \\
\hline Хорватія & $-2,6$ & 2,5 & 3,4 & $-2,5$ & $-4,6$ & $-12,4$ & $-3,8$ \\
\hline Румунія & $-5,7$ & $-3,2$ & $-4,4$ & $-4,4$ & $-9,5$ & $-11,4$ & $-7,5$ \\
\hline Бельгія & $-8,2$ & 2,6 & $-5,2$ & 2,3 & $-11,2$ & $-11,3$ & $-9,5$ \\
\hline Італія & $-6,5$ & 0,0 & $-2,2$ & 1,9 & $-9,8$ & $-11,2$ & $-9,4$ \\
\hline Португалія & $-0,1$ & $-2,2$ & 4,4 & $-1,8$ & $-0,8$ & $-10,5$ & $-3,8$ \\
\hline Угорщина & 1,2 & 0,3 & $-3,1$ & $-5,8$ & $-1,3$ & $-9,2$ & $-4,0$ \\
\hline Німеччина & 2,2 & 3,3 & 0,4 & 0,3 & 0,6 & $-7,7$ & $-5,3$ \\
\hline Люксембург & 4,3 & 6,7 & 0,9 & $-1,8$ & $-0,5$ & $-7,5$ & $-4,8$ \\
\hline Ірландія & $-2,0$ & 1,1 & $-1,2$ & 4,1 & $-3,7$ & $-7,4$ & $-7,4$ \\
\hline Естонія & $-1,7$ & 1,0 & 1,3 & $-0,4$ & $-6,0$ & $-7,3$ & $-1,1$ \\
\hline Чехія & $-0,2$ & 1,8 & 1,0 & $-1,5$ & $-4,2$ & $-7,2$ & $-2,9$ \\
\hline Словаччина & $-0,5$ & $-0,4$ & $-1,0$ & $-3,5$ & $-2,9$ & $-7,1$ & $-5,3$ \\
\hline Фінляндія & $-1,2$ & 2,7 & $-3,8$ & $-1,7$ & $-2,1$ & $-5,6$ & $-8,7$ \\
\hline Литва & $-2,2$ & 3,4 & 0,2 & $-0,6$ & $-4,2$ & $-5,5$ & $-7,0$ \\
\hline Швеція & $-0,9$ & 4,5 & 0,2 & $-1,3$ & $-1,9$ & $-4,0$ & $-2,4$ \\
\hline Данія & 4,4 & 5,3 & 2,7 & 2,8 & $-1,1$ & $-3,6$ & $-0,9$ \\
\hline Болгарія & 4,8 & 4,7 & 1,1 & $-1,9$ & 1,6 & $-2,3$ & $-2,6$ \\
\hline Латвія & 0,6 & 2,5 & 0,8 & $-5,9$ & $-0,2$ & $-1,5$ & $-5,3$ \\
\hline Великобританія & 1,7 & $-4,2$ & $-2,7$ & $-4,0$ & $-0,5$ & $-24,8$ & $-13,6$ \\
\hline
\end{tabular}

Джерело: складено і проранжовано автором (за даними 2020-Q2) з використанням даних Євростату: General government deficit (-) and surplus (+) - quarterly data [TEINA205]. Percentage of gross domestic product (GDP), (NSA).

Практично усі країни ЄС протягом 2020 року наростили державні боргові зобов’язання, які для 15 країн перевищили Маастрихтський критерій у 60\% ВВП (табл.2). Особливо значним у третьому кварталі виявилась величина показника співвідношення валового боргу та ВВП для Греції (199,9\%), Італії $(154,2 \%)$, Португалії (130,8\%), та Кіпру (119,5\%). Для 7 країн величина показника 
перевищила середнє значення для ЄС-27. Для Великобританії величина показника перевищила $100 \%$.

Таблиия 2

Валовий борг державного сектору - квартальні дані країн СС-27 та Великобританії у 2019-2020 рp., \% ВВП

\begin{tabular}{|l|l|l|l|l|l|l|l|}
\hline & $2019-\mathrm{Q} 1$ & $2019-\mathrm{Q} 2$ & $2019-\mathrm{Q} 3$ & $2019-\mathrm{Q} 4$ & $2020-\mathrm{Q} 1$ & $2020-\mathrm{Q} 2$ & $2020-\mathrm{Q} 3$ \\
\hline $\begin{array}{l}\text { Зона євро } 19 \\
\text { країн }\end{array}$ & 86,3 & 86,2 & 85,8 & 84,0 & $86,2 \mathrm{p}$ & 95,0 & 97,3 \\
\hline СС 27 країн & 79,9 & 79,7 & 79,2 & 77,6 & 79,4 & 87,7 & 89,8 \\
\hline Греція & 187,3 & 185,0 & 182,6 & 180,5 & 180,7 & 191,4 & 199,9 \\
\hline Італія & 136,0 & 137,5 & 136,8 & 134,7 & 137,6 & 149,3 & 154,2 \\
\hline Португалія & 122,8 & 120,1 & 119,6 & 117,2 & 119,5 & 126,0 & 130,8 \\
\hline Кіпр & 101,7 & 105,6 & 96,5 & 94,0 & 96,2 & 113,3 & 119,5 \\
\hline Франція & 99,3 & 99,2 & 100,1 & 98,1 & 101,3 & 114,0 & 116,5 \\
\hline Іспанія & 98,4 & 98,4 & 97,5 & 95,5 & 99,0 & 110,2 & 114,1 \\
\hline Бельгія & 102,9 & 101,9 & 101,6 & 98,1 & 103,4 & 114,1 & 113,2 \\
\hline Хорватія & 74,1 & 75,4 & 74,4 & 72,7 & 73,8 & 84,8 & 86,4 \\
\hline Австрія & 72,9 & 71,9 & 71,1 & 70,5 & 73,1 & 82,5 & 79,1 \\
\hline Словенія & 67,8 & 67,4 & 67,7 & 65,6 & 69,0 & 78,3 & 78,5 \\
\hline Угорщина & 68,4 & 67,2 & 67,2 & 65,5 & 65,9 & 70,5 & 74,3 \\
\hline Німеччина & 61,6 & 61,1 & 61,0 & 59,6 & 61,0 & 67,4 & 70,0 \\
\hline Фінляндія & 59,5 & 61,5 & 60,1 & 59,3 & 64,3 & 68,6 & 66,9 \\
\hline Ірландія & 64,7 & 63,0 & 61,3 & 57,4 & 58,9 & 62,7 & 62,0 \\
\hline Словаччина & 49,8 & 49,1 & 48,9 & 48,5 & 49,7 & 60,3 & 60,8 \\
\hline Польща & 48,9 & 47,7 & 47,0 & 45,7 & 47,6 & 54,8 & 56,7 \\
\hline Нідерланди & 50,9 & 51,0 & 49,3 & 48,7 & 49,5 & 55,2 & 55,2 \\
\hline Мальта & 45,7 & 45,0 & 42,7 & 42,4 & 43,9 & 51,0 & 53,7 \\
\hline Литва & 33,6 & 35,7 & 35,4 & 35,9 & 33,0 & 41,4 & 45,9 \\
\hline Латвія & 38,5 & 37,5 & 37,1 & 36,9 & 37,1 & 42,9 & 44,6 \\
\hline Данія & 33,4 & 34,7 & 34,2 & 33,3 & 33,0 & 41,2 & 42,4 \\
\hline Румунія & 33,8 & 33,9 & 35,2 & 35,3 & 37,4 & 40,8 & 43,1 \\
\hline Чехія & 33,4 & 32,6 & 31,5 & 30,2 & 32,7 & 39,9 & 38,4 \\
\hline Швеція & 36,6 & 35,8 & 35,2 & 35,1 & 35,8 & 37,1 & 38,4 \\
\hline Люксембург & 20,7 & 20,3 & 20,1 & 22,0 & 22,2 & 23,9 & 26,1 \\
\hline Болгарія & 20,9 & 20,3 & 20,5 & 20,2 & 20,1 & 21,3 & 25,3 \\
\hline Естонія & 7,8 & 9,1 & 9,0 & 8,4 & 8,9 & 18,5 & 18,5 \\
\hline Великобританія & 84,2 & 84,9 & 84,1 & 85,3 & 84,5 & 96,4 & 101,0 \\
\hline
\end{tabular}

Джерело: складено і проранжовано автором (за даними 2020-Q3) з використанням даних Євростату:General government gross debt - quarterly data [TEINA230] Percentage of gross domestic product (GDP).

Підсумовуючи викладене щодо методологічних засад механізмів забезпечення стійкості сектору державних фінансів та динаміки основних 
індикаторів в умовах розгортання хвилеподібної пандемії COVID-19, слід визнати, що для України та більшості країн ЄС відповідні показники вже вийшли за межі прийнятного для фінансової стабільності діапазону. Зростає ризик кризи державних фінансів у середньостроковій перспективі. Одночасно не можна не погодитися $з$ концептуальними положеннями, наведеними в [24, с. 156]: «3 теорії відомо, що надмірне боргове навантаження знижує потенціал економічного зростання. Деструктивний вплив великого державного боргу реалізується через зростання процентних ставок за позиками, стримування інвестиційної діяльності в країні, посилення макроекономічної волатильності й уразливості до фінансових криз».

Механізми забезпечення стійкості фінансового сектору в межах повноважень регулятора грошово-кредитної сфери та фінансових ринків на прикладі Національного банку України.

Досвід розгортання в Україні валютних і банківських криз під впливом ендогенних чинників та під впливом глобальних та регіональних криз зумовив запровадження після 2016 року моделі банківського регулювання, яка впроваджувалася на міжнародному рівні після 2009 року.

Відповідно до рекомендацій Європейської Ради системних ризиків (ESRB) стратегічні цілі макропруденційної політики досягаються через низку тактичних (проміжних) цілей. Для досягнення проміжних цілей центральні банки та інші регулятори використовують макропруденційний інструментарій. Вибір інструменту залежить від індикаторів та ознак ризику, що виникатимуть у певний момент. Розкриємо це положення на прикладі України.

Система цілей макропруденційної політики України: кінцева ціль фінансова стабільність через підвищення стійкості фінансової системи та недопущення накопичення системних ризиків; проміжні цілі: 1) недопущення надмірного зростання кредитування; 2) недопущення накопичення дефіциту ліквідності; 3) обмеження концентрації ризиків; 4) обмеження впливу викривлених стимулів; 5) підвищення стійкості фінансової інфраструктури [25].

У межах повноважень НБУ макропруденційну політику координує Комітет 3 фінансової стабільності (далі - КФС). Основні завдання КФС - визначення системних ризиків, шляхів їх нівелювання, рекомендацій до застосування макропруденційних інструментів, координація дій підрозділів НБУ для забезпечення фінансової стабільності.

У межах мандата НБУ макропруденційна політика перетинається 3 монетарною політикою та банківським (мікро-пруденційним) наглядом. Вони реагують на різні виклики й мають різні цілі, проте взаємодіють та доповнюють одне одного. Монетарна політика - це складова макроекономічної політики, що має на меті зберегти купівельну спроможність гривні, підтримуючи низькі, 
стабільні темпи інфляції, що передумовою фінансової стабільності. НБУ застосовує інструменти монетарної політики для цілей фінансової стабільності лише тоді, коли системний ризик або ускладнення в роботі фінансових ринків мають суттєвий вплив на перспективи інфляції та економічної активності [25]. Мета банківського нагляду - стабільність банків, захист їхніх вкладників i кредиторів. Однією із ключових цілей банківського нагляду $\epsilon$ вчасна ідентифікація проблем на рівні окремих банків та вчасне реагування, а в окремих випадках - виведення їх із ринку [25]. Варто відзначити, що банківський сектор України не став фактором посилення економічної нестабільності. За даними НБУ у 2020 році він залишався високоприбутковим завдяки стійкості операційних прибутків та відсутності значних кредитних втрат. Зокрема, чистий прибуток банків склав понад 41 млрд. грн. (у 2009 році збитки банків склали понад 38 млрд. грн., у 2015 році - понад 66 млрд. грн.).

Реалізуючи макропруденційну політику НБУ оприлюднює аналітичні публікації та звіти, ключовим з яких є «Звіт про фінансову стабільність». У Звітах 2020 року містяться рекомендації органам влади і фінансовим установам стосовно того, як протидіяти ризикам та сприяти підвищенню стійкості фінансової системи до них в умовах пандемії COVID-19. У звітах наводяться прогнози щодо ризикових ситуацій у грошово-кредитній сфері, зокрема щодо кредитного ризику, ризику достатності капіталу, ризику ліквідності, ризику прибутковості, валютного ризику тощо [26].

В цьому зв'язку варто зазначити, що від початку липня НБУ став регулятором більшості учасників небанківського фінансового ринку, зокрема страхових компаній, кредитних спілок та фінансових компаній. У фокусі найбільшої уваги НБУ будуть кредитні спілки та страхові компанії - саме вони активно працюють із коштами фізичних осіб та бізнесу. Попередній аналіз засвідчив, що багато гравців у цих сегментах недостатньо фінансового стійкі. НБУ ініціює впровадження на страховому ринку підходів до регулювання та нагляду, що базуватимуться на пакеті законодавства ЄC Solvency. Це дасть змогу посилити платоспроможність i ліквідність страхових компаній, поліпшити конкурентне середовище та краще захищати права споживачів фінансових послуг. Крім того, НБУ розширить макропруденційне регулювання на небанківський сектор, хоча він не $є$ джерелом помітних системних ризиків через невеликий розмір та простоту фінансових продуктів [26, с. 5].

Висновки. Пандемія COVID-19 другий рік поспіль є тригером актуалізації ризиків стабільного функціонування національних фінансових систем. Безпрецедентні витрати держав на боротьбу з пандемією, забезпечення лікування та вакцинації населення, фінансову підтримку найбільш вразливих груп населення та окремих секторів національних економік спричинили кількаразове 
зростання дефіцитів державних бюджетів та стрімке збільшення боргового навантаження на сферу державних фінансів. Зазначене у середньостроковій перспективе потребуватиме перегляду бюджетної політики та стратегії управління державним боргом.

Досвід боротьбі з кризовими явищами останнього десятиліття дозволив світовій спільноті розробити ефективні механізми забезпечення стійкості національних фінансових систем в межах повноважень національних банків 3 використанням методів та інструментів макропруденціальної політики, посилення банківського нагляду i збереження функціональної спроможності грошовокредитної сфери. Про це свідчать дані звітів про фінансову стабільність НБУ.

\section{Jimepamypa:}

1. Schinasi Garry J. Defining Financial Stability. IMF Working Papers. October 2004. WP/04/187. 19 p. URL: https://www.imf.org/external/pubs/ft/wp/2004/wp04187.pdf.

2. Vasilescu M. Financial stability - a theoretical approach. Annals of the "Constantin Brâncuşi" University of Târgu Jiu, Economy Series, Issue 1/2012. URL: https://www.utgjiu.ro/revista/ec/pdf/2012-01/18_MARIA_VASILESCU.pdf.

3. Хуторна M.Е. Теоретико-методологічні підходи до тлумачення фінансової стабільності макро- та мікрорівневих економічних систем. Науковий вісник Ужгородського університету. 2017. Серія Економіка. Випуск 1 (49). С. 295-303.

4. Хоршева О.С. Проблемы устойчивости национальной финансовой системы и пути их решения. URL: https://files.scienceforum.ru/pdf/2015/11951.pdf.

5. Джаксыбекова Г.Н. Критерии финансовой устойчивости финансовой системы Республики Казахстан. URL: https://www.almau.edu.kz/images/uploads/files/ e830f08736e6f57fb0f644224bf2c004.pdf.

6. Подкуйко М.С. Финансовая стабильность стран в условиях глобализации. Финансовые исследования. 2007. № 15. 2007. С 17-26.

7. Краснов А.Ю. Устойчивость государственных финансов Кыргызской Республики: теоретико-методологический аспект. Вестник КРСУ. 2017. Том 17. № 2. С. 22-26.

8. Грибач О.В. Діагностика фінансової нестабільності в умовах глобальної економічної кризи. Глобальні та національні проблеми економіки. Миколаївський національний університет імені В.О. Сухомлинського Випуск 8. 2015. С 35-38. URL: http://global-national.in.ua/issue-82015/16-vipusk-8-listopad-2015-r/1386-gribach-o-v-diagnostika-finansovoji-nestabilnosti-v-umovakhglobalnoji-ekonomichnoji-krizi

9. Гриценко А.А. Стабільність грошової одиниці та стійкість фінансової системи: зміна базових співвідношень. Проблеми та перспективи забезпечення стійкості фінансової системи України: зовнішні та внутрішні аспекти: збірник матеріалів міжнародної наукової конференції / НАН України, ДУ «Ін-т екон. та прогнозув. НАН України». К.: 2020. С. 7-12. URL: http://ief.org.ua/docs/scc/15.pdf

10. Шемаєва Л.Г. Проблеми та перспективи зміцнення стійкості фінансової системи України Проблеми та перспективи забезпечення стійкості фінансової системи України: зовнішні та внутрішні аспекти: збірник матеріалів міжнародної наукової конференції / НАН України, ДУ «Ін-т екон. та прогнозув. НАН України». К.: 2020. С. 22-29. URL: http://ief.org.ua/docs/scc/15.pdf

11. Шевченко Л. М. Содержание и проблемы устойчивости национальной финансовой 
системы. Финансы и кредит. 2012. 24 (504). С. 29-34.

12. Сльозко О.О., Панфілова Т.О., Терещенко С.В. Сучасні проблеми реформування світової фінансової системи К.: Інститут світової економіки і міжнародних відносин НАН України. 2013. 194 с.

13. Показатели финансовой устойчивости. Руководство по составлению. Международный Валютный Фонд. 2007. 312 с.

14. Шинази Г.Дж. Сохранение финансовой стабильности. Вопросы экономики. 2005. № 36. Международный Валютный Фонд. 26 с.

15. Громова А.С. Финансовая устойчивость и безопасность бюджетной системы как ключевые факторы развития национальной экономики. Вестник Томского государственного университета. Экономика. 2012. №1(17). С. 154-160.

16. Розвиток фінансових інститутів ЄС та виклики для фінансової політики України: монографія / [Борзенко О.О., Богдан Т.П., Шаров О.М. та ін.]; НАН України, ДУ«Ін-т екон. та прогнозув. НАН України». К.: 2019. 372 с.

17. Bova E., Carcenac N., Guerguil M. Fiscal Rules and the Procyclicality of Fiscal Policy in the Developing World. IMF Working Paper. WP/14/122. 2014. 27 p.

18. Інформація про фіскальні ризики та їх вплив на показники державного бюджету у 2020 році. Міністерство фінансів України. 24 с. URL: https://mof.gov.ua/uk/zvity.

19. Держбюджет-2020: Показник дефіциту забезпечено на рівні 217,6 млрд. грн.. (5,2\% ВВП). Міністерство фінансів України. 01.04.2021. URL: https://www.mof.gov.ua/uk/news/derzhbiudzhet2020_pokaznik_defitsitu_zabezpecheno_na_rivni_2176_mlrd_grn_52_vvp-2805

20. Звіт про фінансову стабільність. Грудень 2020 року. Національний банк України. 49 с. URL: https://bank.gov.ua/ua/news/all/zvit-pro-finansovu-stabilnist-gruden-2020-roku

21. Про затвердження Середньострокової стратегії управління державним боргом на 2019-2022 роки. Постанова КМУ від 05 червня 2019 р. № 473. URL: https://www.kmu.gov.ua/npas/prozatverdzhennya-serednostrokovoyi-strategiyi-upravlinnya-derzhavnim-borgom-na-20192022-roki

22. Ostry J.D., Ghosh A.R. Obstacles to International Policy Coordination, and How to Overcome Them. IMF Staff Discussion Note. 2013. № SDN/13/11. 31 p.

23. У лютому 2021 року державний та гарантований державою борг України знизився на 5,3 млрд грн. 25 Березня 2021. Міністерство фінансів України. URL: https://www.mof.gov.ua/uk/news/u_liutomu_2021_roku_derzhavnii_ta_garantovanii_derzhavoiu_borg _ukraini_znizivsia_na_53_mlrd_grn-2793

24. Фінансова глобалізація і євроінтеграція / за ред. О.Г. Білоруса, Т.І. Єфименко. ДННУ “Акад. фін. управління”. К.: 2015. 496 с.

25. Стратегія макропруденційної політики. Національний банк України. 2020. 24 с. URL: https://bank.gov.ua/admin_uploads/article/Strategy_MaP.pdf?v=4

26. Звіт про фінансову стабільність. Червень 2020 р. Національний банк України. 51 с. URL: https://bank.gov.ua/ua/news/all/zvit-pro-finansovu-stabilnist-cherven-2020-roku

\section{References:}

1. Schinasi, Garry J. (2004). Defining Financial Stability. IMF Working Papers. WP/04/187. 19 p. Retrieved from: https://www.imf.org/external/pubs/ft/wp/2004/wp04187.pdf.

2. Vasilescu, M. (2012). Financial stability - a theoretical approach. Annals of the "Constantin Brâncuşi” University of Târgu Jiu, Economy Series, Issue 1/2012. Retrieved from: https://www.utgjiu.ro/revista/ec/pdf/2012-01/18_MARIA_VASILESCU.pdf. 
3. Khutorna, M.E. (2017) Teoretyko-metodolohichni pidkhody do tlumachennya finansovoyi stabil'nosti makro- ta mikrorivnevykh ekonomichnykh system [Theoretical and methodological approaches to the interpretation of financial stability of macro- and micro-level economic systems]. Naukovyy visnyk Uzhhorods'koho universytetu. Seriya Ekonomika. - Scientific Bulletin of Uzhhorod University. Series Economics, 1(49), 295-303 [in Ukrainian].

4. Khorsheva, O.S. (2015) Problemy ustoychivosti natsional'noy finansovoy sistemy i puti ikh resheniya [Problems of stability of the national financial system and ways of their solution]. Retrieved from: https://files.scienceforum.ru/pdf/2015/11951.pdf [in Russian].

5. Dzhaksybekova, G.N. Kriterii finansovoy ustoychivosti finansovoy sistemy Respubliki Kazakhstan [Criteria of financial stability of the financial system of the Republic of Kazakhstan]. Retrieved from: https://www.almau.edu.kz/images/uploads/ files/e830f08736e6f57fb0f644224bf2c004.pdf [in Russian].

6. Podkuyko, M.S. (2007). Finansovaya stabil'nost' stran v usloviyakh globalizatsii [Financial stability of countries in the context of globalization]. Finansovyye issledovaniya - Financial research, 15, 17-26 [in Russian].

7. Krasnov, A.Yu. (2017). Ustoychivost' gosudarstvennykh finansov Kyrgyzskoy Respubliki: teoretiko-metodologicheskiy aspekt [Stability of public finances of the Kyrgyz Republic: theoretical and methodological aspect]. Vestnik KRSU - KRSU Bulletin, T.17, 2, 22-26 [in Russian].

8. Hrybach, O.V. (2015). Diahnostyka finansovoyi nestabil'nosti v umovakh hlobal'noyi ekonomichnoyi kryzy [Diagnosis of financial instability in the global economic crisis]. Hlobal'ni ta natsional'ni problemy ekonomiky. Mykolayivs'kyy natsional'nyy universytet imeni V.O. Sukhomlyns'koho, - Global and national economic problems. Mykolayiv National University named after VO Sukhomlinsky. Issue 8. 35-38 [in Ukrainian].

9. Hrytsenko, A.A. (2020) Stabil'nist' hroshovoyi odynytsi ta stiykist' finansovoyi systemy: zmina bazovykh spivvidnoshen' [Stability of the monetary unit and stability of the financial system: change of basic relations]. Problemy ta perspektyvy zabezpechennya stiykosti finansovoyi systemy Ukrayiny: zovnishni ta vnutrishni aspekty: zbirnyk materialiv mizhnarodnoyi naukovoyi konferentsiyi / NAN Ukrayiny, DU «In-t ekon. ta prohnozuv. NAN Ukrayiny»-Problems and prospects of ensuring the stability of the financial system of Ukraine: external and internal aspects: collection of materials of the international scientific conference / NAS of Ukraine, SI "Inst. of Econ. and Forecasting NAS of Ukraine", 7-12. Retrieved from: http://ief.org.ua/docs/scc/15.pdf [in Ukrainian].

10. Shemayeva, L.H. (2020) Problemy ta perspektyvy zmitsnennya stiykosti finansovoyi systemy Ukrayiny [Problemy ta perspektyvy zmitsnennya stiykosti finansovoyi systemy Ukrayiny]. Problemy ta perspektyvy zabezpechennya stiykosti finansovoyi systemy Ukrayiny: zovnishni ta vnutrishni aspekty: zbirnyk materialiv mizhnarodnoyi naukovoyi konferentsiyi / NAN Ukrayiny, DU «In-t ekon. ta prohnozuv. NAN Ukrayiny»-Problems and prospects of ensuring the stability of the financial system of Ukraine: external and internal aspects: collection of materials of the international scientific conference / NAS of Ukraine, SI "Inst. of Econ. and Forecasting NAS of Ukraine”, 22-29. Retrieved from: http://ief.org.ua/docs/scc/15.pdf [in Ukrainian].

11. Shevchenko, L.M. (2012) Soderzhaniye i problemy ustoychivosti natsional'noy finansovoy sistemy [Content and problems of stability of the national financial system]. Finansy $i$ kredit - Finance and credit, 24 (504), 29-34. [in Russian].

12. Sl'ozko, O.O., Panfilova, T.O., \& Tereshchenko, S.V. (2013) Suchasni problemy reformuvannya svitovoyi finansovoyi systemy [Modern problems of reforming the world financial system]. K.: Instytut svitovoyi ekonomiky i mizhnarodnykh vidnosyn NAN Ukrayiny [in Ukrainian].

13. Pokazateli finansovoy ustoychivosti. Rukovodstvo po sostavleniyu [Financial Soundness 
Indicators: Compilation Guide ]. (2007) Mezhdunarodnyy Valyutnyy Fond - International Monetary Fund [in Russian].

14. Shinazi, G.Dzh. (2005) Sokhraneniye finansovoy stabil'nosti [Maintaining financial stability]. Voprosy ekonomiki - Economic issues, 36 [in Russian].

15. Gromova, A.S. (2012) Finansovaya ustoychivost' i bezopasnost' byudzhetnoy sistemy kak klyuchevyye faktory razvitiya natsional'noy ekonomiki [Financial stability and security of the budgetary system as key factors in the development of the national economy]. Vestnik Tomskogo gosudarstvennogo universiteta. Ekonomika. - Bulletin of Tomsk State University. Economy, 1(17), 154-160. [in Russian].

16. Borzenko, O.O., Bohdan, T.P., \& Sharov, O.M. (2020) Rozvytok finansovykh instytutiv YES ta vyklyky dlya finansovoyi polityky Ukrayiny: monohrafiya [Borzenko, O.O., Bogdan, T.P., \& Sharov, O.M. etc. Development of EU financial institutions and challenges for financial policy of Ukraine: monograph]. NAN Ukrayiny, DU «In-t ekon. ta prohnozuv. NAN Ukrayiny» - NAS of Ukraine, SI "Inst. of Economics and Forecasting. NAS of Ukraine" [in Ukrainian].

17. Bova E., Carcenac N., Guerguil M. (2014) Fiscal Rules and the Procyclicality of Fiscal Policy in the Developing World. IMF Working Paper. WP/14/122. 2014. 27 p.

18. Informatsiya pro fiskal'ni ryzyky ta yikh vplyv na pokaznyky derzhavnoho byudzhetu u 2020 rotsi [Information on fiscal risks and their impact on the state budget in 2020] (2020). Ministerstvo finansiv Ukrayiny - Ministry of Finance of Ukraine. Retrieved from: https://mof.gov.ua/uk/zvity [in Ukrainian].

19. Derzhbyudzhet-2020: Pokaznyk defitsytu zabezpecheno na rivni $217,6 \mathrm{mlrd}$. hrn.. (5,2\% VVP) [State Budget 2020: The deficit indicator is provided at the level of UAH 217.6 billion (5.2\% of GDP)]. Ministerstvo finansiv Ukrayiny - Ministry of Finance of Ukraine. (n.d.) mof.gov.ua. Retrieved from: https://www.mof.gov.ua/uk/news/derzhbiudzhet-2020_pokaznik_defitsitu_zabezpecheno_na_rivni_ 2176_mlrd_grn_52_vvp-2805 [in Ukrainian].

20. Zvit pro finansovu stabil'nist'. Hruden' 2020 roku [Financial Stability Report. December 2020]. Natsional'nyy bank Ukrayiny - National Bank of Ukraine. (n.d.) bank.gov.ua. Retrieved from: https://bank.gov.ua/ua/news/all/zvit-pro-finansovu-stabilnist-gruden-2020-roku

21. Pro zatverdzhennya Seredn'ostrokovoyi stratehiyi upravlinnya derzhavnym borhom na 2019-2022 roky. Postanova KMU vid 05 chervnya 2019 r. [On approval of the Medium-Term Public Debt Management Strategy for 2019-2022. Resolution of the Cabinet of Ministers of June 5, 2019]. (n.d.). kти.gov.ua. Retrieved from: https://www.kmu.gov.ua/npas/pro-zatverdzhennyaserednostrokovoyi-strategiyi-upravlinnya-derzhavnim-borgom-na-20192022-roki

22. Ostry, J.D., Ghosh, A.R. (2013). Obstacles to International Policy Coordination, and How to Overcome Them. IMF Staff Discussion Note. № SDN/13/11. 31 p.

23. U lyutomu 2021 roku derzhavnyy ta harantovanyy derzhavoyu borh Ukrayiny znyzyvsya na $5,3 \mathrm{mlrd}$ hrn. [In February 2021, Ukraine's public and state-guaranteed debt decreased by UAH 5.3 billion]. Ministerstvo finansiv Ukrayiny, 25 Bereznya 2021 - Ministry of Finance of Ukraine, March 25, 2021. (n.d.).mof.gov.ua. Retrieved from: https://www.mof.gov.ua/uk/news/u_liutomu_2021_roku_ derzhavnii_ta_garantovanii_derzhavoiu_borg_ukraini_znizivsia_na_53_mlrd_grn-2793.

24. Bilorus, O.H., Yefymenko, T.I. (2015). Finansova hlobalizatsiya i yevrointehratsiya [Financial globalization and European integration]. DNNU “Akad. fin. upravlinnya" - DNNU "Acad. Finn. management".

25. Stratehiya makroprudentsiynoyi polityky [Macroprudential policy strategy]. NBU. (n.d.). bank.gov.ua. Retrieved from: https://bank.gov.ua/admin_uploads/article/Strategy_MaP.pdf?v=4. 
26. Zvit pro finansovu stabil'nist'. Cherven' 2020 roku [Financial Stability Report. June 2020]. Natsional'nyy bank Ukrayiny - National Bank of Ukraine. (n.d.) bank.gov.ua. Retrieved from: https://bank.gov.ua/ua/news/all/zvit-pro-finansovu-stabilnist-cherven-2020-roku. 